\title{
DAYA TERIMA KONSUMEN TERHADAP ROTI MANIS YANG DISUBTITUSI MODIFIED TALIPUK FLOUR (MOTAF) DAN PATI TEMULAWAK
}

\section{CONSUMER ACCEPTANCE TOWARDS SWEET BREAD SUBTITUTED TO MODIFIED TALIPUK FLOUR (MOTAF) AND TEMULAWAK STARCH}

\author{
Dwi Sandri dan Ema Lestari* \\ Jurusan Teknologi Industri Pertanian, Politeknik Negeri Tanah Laut \\ JL. A. Yani, Km. 6 Desa Panggung Kecamatan Pelaihari, Kabupaten Tanah Laut, Kalimantan Selatan \\ *Email korespondensi: emalestari@politala.ac.id
}

Diterima 06-10-2020, diperbaiki 03-11-2020, disetujui 13-11-2020

\begin{abstract}
This study aimed to analyze the consumer's acceptance towards sweet bread substituted to Modified Talipuk Flour (MOTAF) and temulawak starch. This research was conducted using a completely randomized design method (CRD) which consisted of 5 treatments consisting of the ratio of wheat flour, motaf, and ginger starch flour. The sweet bread of these 5 treatments was tested for specific volume and level of consumer preference which consisted of taste, aroma, and texture. The data obtained were then analyzed by ANOVA and followed by further DMRT test at the 5\% level. The results showed that consumers could receive sweet bread substituted for Motaf and temulawak starch which in terms of aroma and texture showed no significant difference to bread 100\% wheat flour, while in terms of taste in treatment $C$ (substitution of Motaf and Temulawak Starch Flour) has a taste similar to $100 \%$ wheat bread with a score of 6.31 . Whereas for the specific volume there was a significant difference in each treatment where the bread in treatment $C$ had a greater value than the $100 \%$ wheat bread. The addition of temulawak starch will have an effect on the bread yield, the more temulawak starch was added, the quality of the bread will decrease.
\end{abstract}

Keywords: Modified talipuk flour (motaf), temulawak starch, sweet bread

\begin{abstract}
ABSTRAK
Penelitian ini bertujuan menganalisis daya terima konsumen terhadap roti manis yang disubtitusi Modified Talipuk Flour (MOTAF) dan pati temulawak. Penelitian ini dilakukan dengan metode Rancangan Acak Lengkap (RAL) yang terdiri dari 5 perlakuan dengan perbandingan tepung terigu, motaf, dan tepung pati temulawak. Roti manis dari 5 perlakuan ini dilakukan pengujian volume spesifik dan tingkat kesukaan konsumen yang terdiri dari rasa, aroma, dan tekstur. Data yang diperoleh kemudian dianalisis dengan ANOVA dan dilanjutkan dengan uji lanjut DMRT pada taraf $5 \%$. hasil penelitian menunjukan bahwa konsumen dapat menerima roti manis yang disubtitusi Motaf dan tepung pati temulawak dimana ditinjau dari segi aroma dan tekstur menunjukan perbedaan tidak nyata terhadap roti $100 \%$ tepung terigu, sedangkan ditinjau dari segi rasa pada perlakuan C (subtitusi Motaf dan Tepung Pati Temulawak) memiliki rasa yang mirip seperti roti $100 \%$ terigu dengan skor 6,31 . Sedangkan untuk volume spesifik memliki beda signifikan pada setiap perlakuan dimana roti pada perlakuan C memiliki nilai yang lebih besar dari pada roti $100 \%$ terigu. Penambahan temulawak
\end{abstract}


akan memberikan pengaruh terhadap hasil roti, semakin banyak ditambahkan temulawak, maka kualitias roti akan semakin berkurang.

Kata Kunci: Modified talipuk flour (motaf), pati temulawak, roti manis

\section{PENDAHULUAN}

Indonesia merupakan salah satu negara yang memiliki sumber daya hayati yang sangat beragam, dimana salah satu potensinya dapat dijadikan sebagai sumber pangan. Menurut data, Indonesia merupakan negara pengimpor gandum terbanyak didunia sebesar 10.692.978 juta ton. Ini merupakan $6,1 \%$ dari jumlah total impor dunia (BPS-Statistics Indonesia, 2020). Kondisi ini kemungkinan tidak akan berubah karena pesatnya konsumsi kebutuhan domestik terhadap gandum.

Salah satu produk yang terbuat dari terigu yang sekarang banyak diminati dan berkembang pesat adalah roti. Pada pembuatan roti saat ini didominasi dengan penggunaan tepung terigu, karena mengandung gluten. Saat ini, tepung untuk membuat roti harus mengandung gluten, yang hanya terdapat dalam terigu (Yuwono dan waziiroh, 2019). Tetapi tidak semua orang dapat mengonsumsi terigu karena alergi terhadap terigu, seperti penderita autis. Selain autis, dikenal pula penyakit seliak atau sering disebut celiac disease, nontropical sprue, enteropati gluten, atau celiac sprue, yaitu penyakit menurun pada seseorang yang tubuhnya tidak toleran terhadap gluten (Richana, 2010).

Berbagai upaya untuk mengurangi ketergantungan tepung terigu salah satunya dengan memanfaatkan tanaman talipuk (Nymphaea pubescens Willd) dan temulawak (Curcuma xanthorrhiza Roxb.). Talipuk merupakan salah satu tumbuhan yang telah banyak dimanfaatkan oleh masyarakat Hulu Sungai Utara, Kalimantan Selatan sebagai sumber bahan pangan. Salah satu bagian yang dimanfaatkan adalah biji talipuk. Biji talipuk dapat diubah menjadi Modified Talipuk Flour (MOTAF) dengan kandungan protein tinggi dan telah memenuhi Standar Nasional Indonesia untuk tepung terigu (Fatimah et al., 2017). MOTAF dapat dimanfaat sebagai bahan dasar pembuatan aneka kue, salah satunya adalah Roti manis. Hasil penelitian menyebutkan MOTAF mampu mensubtitusi tepung terigu sebesar 5\% dalam pembuatan roti manis (Lestari et al., 2019).

Selain talipuk, temulawak juga memiliki potensi yang sangat besar diversifikasi olahan pangan. Pada ekstrak temulawak ditemukan kadar kurkumin sebesar 27,19\% dengan aktivitas antioksidan ekstrak temulawak dengan $\mathrm{IC}_{50}$ sebesar 87,01 ppm yang tergolong aktif sehingga berpotensi sebagai antioksidan alami yang baik (Rosidi et al., 2014). Meskipun memiliki banyak manfaat yang terkandung dalam temulawak, dari segi tingkat kesukaan rasa masyarakat masih banyak yang tidak suka mengkonsumsinya karena rasanya yang pahit dan tidak enak. Oleh karena itu butuh diversifikasi temulawak menjadi produk yang dapat diterima masyarakat secara luas yaitu dengan membuatnya menjadi roti manis dengan subtitusi MOTAF agar dapat dijadikan sebagai pangan fungsional berbasis bahan lokal yang kaya akan gizi dan disukai oleh masyarakat. Penelitian ini bertujuan menganalisis daya terima konsumen terhadap roti manis yang disubtitusi Modified Talipuk Flour (MOTAF) dan pati temulawak.

\section{METODE PENELITIAN}

\section{Bahan}

Bahan yang digunakan pada penelitian ini adalah pati temulawak, Modified Talipuk Flour (MOTAF) tepung terigu protein tinggi ${ }^{\circledR}$ Cakra Kembar, telur ayam, garam, gula, Ragi roti ${ }^{\circledR}$ Fermipan, 
bread improver ${ }^{\circledR}$ Bakerin plus, air bersih, susu bubuk, margarine, dan biji wijen.

\section{Alat}

Alat yang digunakan pada penelitian ini adalah pisau, parutan, ayakan, loyang, timbangan, mangkok, sendok, mixer, baskom besar, nampan, kuas, penjepit, gelas ukur, penggaris.

\section{Rancangan Penelitian}

Penelitian ini dilakukan dengan metode Rancangan Acak Lengkap (RAL) dengan satu faktor yang teridiri dari 5 taraf yang diulang sebanya tiga kali. Adapun objek yang diamati adalah dosis pati temulawak dalam mensubtitusi tepung terigu yaitu dosis temulawak sebesar $0.1 \%$ (E), $0.05 \%$ (D), dan $0.01 \%$ (C), dengan kontrol A (100\% terigu) dan kontrol B (95\% terigu : 5\% MOTAF). Adapun perbandingan tepung terigu, motaf, dan tepung pati temulawak seperti terlihat pada tabel 1.

Tabel 1. Formulasi roti manis Motaf Temulawak

\begin{tabular}{lccccc}
\hline Formulasi & $\mathbf{A}$ & $\mathbf{B}$ & $\mathbf{C}$ & $\mathbf{D}$ & $\mathbf{E}$ \\
\hline Motaf $(\mathrm{g})$ & $\mathbf{0}$ & $\mathbf{5}$ & $\mathbf{5}$ & $\mathbf{5}$ & $\mathbf{5}$ \\
Tepung terigu $(\mathrm{g})$ & $\mathbf{1 0 0}$ & $\mathbf{9 5}$ & $\mathbf{9 4 , 9 9}$ & $\mathbf{9 4 , 9 4}$ & $\mathbf{9 4 , 9 0}$ \\
Tepung pati temulawak $(\mathrm{g})$ & $\mathbf{0}$ & $\mathbf{0}$ & $\mathbf{0 , 0 1}$ & $\mathbf{0 , 0 5}$ & $\mathbf{0 , 1}$ \\
Susu bubuk $(\mathrm{g})$ & 9 & 9 & 9 & 9 & 9 \\
Ragi $(\mathrm{g})$ & 6,6 & 6,6 & 6,6 & 6,6 & 6,6 \\
Margarine $(\mathrm{g})$ & 60 & 60 & 60 & 60 & 60 \\
Gula (g) & 120 & 120 & 120 & 120 & 120 \\
Bread improver $(\mathrm{g})$ & 1 & 1 & 1 & 1 & 1 \\
Telur (butir) & 1 & 1 & 1 & 1 & 1 \\
Air (ml) & 150 & 150 & 150 & 150 & 150 \\
Garam halus $(\mathrm{g})$ & 5 & 5 & 5 & 5 & 5 \\
\hline
\end{tabular}

Roti manis yang telah dibuat ini kemudian dilakukan pengujian volume spesifik dan tingkat kesukaan konsumen yang terdiri dari rasa, aroma, dan tekstur. Data yang diperoleh dianalsis dengan ANOVA dan dilanjutkan dengan uji lanjut DMRT pada taraf 5\%. Analisis statistik ini menggunakan SPSS 26.

\section{Pembuatan Tepung Pati Temulawak}

Temulawak dikupas dari kulit arinya, dicuci sampai bersih, diparut kemudian dicampurkan air dengan perbandingan antara temulawak dan air yaitu 2:1, lalu diaduk sampai air dan temulawak parut tercampur. Kemudian disaring menggunakan saringan 60 mesh. Pati temulawak yang tercampur air diendapkan, pati yang sudah mengendap dibuang airnya dan dibilas dengan air yang baru sambil diaduk untuk menghilangkan getah yang terikut dalam pati temulawak. Pembilasan dilakukan berulang-ulang sebanyak 24 kali hingga air bilasan terlihat jernih dan di dapatkan tepung pati temulawak yang bersih. Kemudian dibuang air bilasan terakhir dan dijemur tepung pati temulawak dibawah terik sinar matahari hingga kering dengan kadar air $\pm 10 \%$ (Lestari et al., 2019)

\section{Pembuatan Modified Talipuk Flour (Motaf)}

Biji talipuk yang digunakan adalah yang telah dilakukan pemisahan kulit ari secara mekanis. Biji tersebut kemudian difermentasi dengan penambahan ragi tape sebanyak $6 \%$ dari jumlah biji talipuk yang digunakan. Biji talipuk difermentasi selama 16 jam dan ditutup dalam kondisi aerob dengan menggunakan plastik yang diberi lubang kecil jarum pada suhu ruang. Setelah biji talipuk difermentasi selama 16 jam, biji talipuk di cuci sampai bersih. Kemudian biji talipuk dijemur dibawah terik matahari selama kurang lebih 2 hari 
sampai mengering dengan kadar air berkisar $10 \%$. Kemudian biji talipuk terfermentasi tersebut dihaluskan dengan blender, lalu tepung diayak menggunakan saringan 60 mesh agar tepung yang dihasilkan bersifat lembut dan halus (Fatimah et al., 2017).

\section{Pembuatan Roti Manis}

Pembuatan produk roti manis menurut Lestari et al. (2019), dengan menggunakan dua tahap yaitu tahap 1 dilakukan dengan menyiapkan bahan biang yaitu susu, gula, telur dan ragi. Susu sebanyak $150 \mathrm{ml}$ dicampur dengan gula 120 gram kemudian dipanaskan $\left( \pm 70^{\circ} \mathrm{C}\right)$, diaduk hingga larut, dan dihentikan pemanasannya. Satu butir telur dimasukan kedalam campuran, diaduk hingga tercampur rata, dan dipastikan larutannya hangat $\left( \pm 40^{\circ} \mathrm{C}\right)$ kemudian dimasukkan 6,6 gram ragi dan diaduk hingga rata lalu didiamkan hingga cairan mengental dan berbusa ( \pm 10 menit). Tahap 2 dilakukan dengan memasukkan biang yang sudah siap ke dalam 300 gram campuran tepung terigu, motaf dan tepung pati temulawak (sesuai kombinasi formulasi pada Tabel 1), 5 gram garam dan 1 gram bread improver, kemudian diaduk hingga tercampur rata. Margarine 60 gram ditambahkan kedalam adonan, lalu diuleni hingga kalis, dan setelah kalis, adonan ditutup menggunakan plastik wrapping selama kurang lebih 1 jam hingga adonan mengembang. Adonan kemudian dibentuk dan didiamkan diloyang yang telah diolesi oleh mentega selama \pm 30 menit agar adonan mengembang, selanjutnya dioven selama 20 menit pada suhu $150{ }^{\circ} \mathrm{C}$.

\section{Analisis Hedonik (Kesukaan)}

Uji kesukaan dilakukan oleh 30 orang panelis tidak terlatih (15 orang laki-laki dan 15 orang perempuan), panelis diminta tanggapan pribadinya tentang kesukaan atau sebaliknya (ketidaksukaan) secara spontan dengan mengisi score sheet uji hedonik dalam hal kesukaan dengan skala (9) amat sangat suka, (8) sangat suka, (7) suka, (6) agak suka, (5) netral, (4) agak tidak suka, (3) tidak suka, (2) sangat tidak suka dan (1) amat sangat tidak suka (Badan Standardisasi Nasional, 2006). Parameter yang diamati meliputi rasa, aroma, dan tekstur.

\section{Analisis Volume Spesifik Roti yang Dimodifikasi \\ Analisis volume spesifik menggunakan metode rapeseed} displacement test yang dimodifikasi. Modifikasi dilakukan pada penggantian rapeseed dengan biji wijen. Pengukuran volume wadah dilakukan dengan memasukkan biji wijen ke dalam wadah hingga penuh dan permukaan wadah diratakan menggunakan penggaris. Biji wijen yang telah dimasukkan ke dalam wadah tersebut diukur volumenya menggunakan gelas ukur untuk mendapatkan volume wadah. Volume roti diukur dengan memasukkan roti ke dalam suatu wadah yang sudah diketahui volumenya dan diisi hingga penuh oleh biji wijen. Setelah roti dikeluarkan dari wadah, biji wijen yang ada di dalam gelas ukur tersebut diukur volumenya menggunakan gelas ukur. Volume roti diperoleh dengan cara mengurangi volume wadah dengan volume biji wijen pada wadah yang telah berisi roti. Volume spesifik dihitung dengan membagi volume roti dengan bobot roti $\left(\mathrm{cm}^{3} / \mathrm{g}\right)(\mathrm{AACC}, 2011)$.

\section{HASIL DAN PEMBAHASAN}

\section{Analisis Hedonik (Kesukaan)}

Uji organoleptik dilakukan terhadap rasa, aroma, dan tekstur. Uji ini bertujuan untuk mengetahui tingkat kesukaan panelis terhadap roti manis MOTAF temulawak. Hasil uji terlihat pada Tabel 2. 
Tabel 2. Hasil Uji Hedonik Roti Manis MOTAF Temulawak

\begin{tabular}{cccc}
\hline \multirow{2}{*}{ Perlakuan } & \multicolumn{3}{c}{ Uji Hedonik (kesukaan) } \\
\cline { 2 - 4 } & Rasa & Aroma & Tekstur \\
\hline A & $6,71 \pm 0,32^{\mathrm{b}}$ & $6,48+0,45^{\mathrm{a}}$ & $6,38 \pm 0,49^{\mathrm{a}}$ \\
B & $6,37 \pm 0,38^{\mathrm{c}}$ & $6,00 \pm 0,20^{\mathrm{a}}$ & $5,70 \pm 0,54^{\mathrm{a}}$ \\
C & $6,31 \pm 0,30^{\mathrm{bc}}$ & $6,00 \pm 0,47^{\mathrm{a}}$ & $5,97 \pm 0,64^{\mathrm{a}}$ \\
D & $6,12 \pm 0,22^{\mathrm{b}}$ & $6,00 \pm 0,12^{\mathrm{a}}$ & $5,86 \pm 0,21^{\mathrm{a}}$ \\
E & $6,11 \pm 0,24^{\mathrm{a}}$ & $6,00 \pm 0,23^{\mathrm{a}}$ & $5,81 \pm 0,25^{\mathrm{a}}$ \\
\hline
\end{tabular}

Ket: Rerata yang diikuti huruf yang berbeda dalam kolom yang sama menunjukan perbedaan nyata pada taraf signifikan $5 \%(\mathrm{p}<0.05)$

\section{Rasa}

Hasil analisis menunjukan bahwa rasa roti manis pada setiap perlakuan terdapat perbedaan nyata $(0.001<0.05)$. Semakin banyak penambahan pati temulawak, panelis memberikan penilaian semakin kurang suka (perlakuan E dengan skor 6,11 yang menunjukan agak suka). Hal ini disebabkan karena tepung pati temulawak memberikan rasa yang sedikit pahit. Menurut Subagja (2014), temulawak mempunyai aroma yang tajam dengan, rasa pahit agak pedas. Tetapi dilain sisi, penambahan temulawak pada produk makanan memiliki nilai keunggulan dari sisi kesehatan, serta dapat menambah masa simpan sehingga akan meningkatkan nilai tambah temulawak (Khamidah et al., 2017)

\section{Aroma}

Aroma merupakan salah satu parameter sensori yang penting dan dapat mempengaruhi seseorang dalam menilai suatu produk makanan (Sutriono dan Pato, 2016). Hasil analisis menunjukan bahwa roti manis dengan penambahan pati temulawak dapat diterima oleh konsumen dengan nilai 6.00 (agak suka). Aroma roti manis pada setiap perlakukan tidak ada perbedaan nyata $(0.334>0.05)$ dimana roti manis dengan penambahan temulawak memiliki aroma yang mirip seperti roti yang hanya berbahan baku tepung terigu (perlakuan A) dan MOTAF (perlakuan B). Hal ini disebabkan karena jumlah pati temulawak yang ditambahkan dengan jumlah yang sedikit antara 0,01 gram $-0,1$ gram. Rasa manis pada roti disebabkan oleh adanya penambahan gula serta peran Saccaharomyces cerevisiae yang berfungsi mengembangkan adonan roti dengan mengkonversi pati menjadi gula kemudian gula dikonversi menjadi alkohol dan gas $\mathrm{CO}_{2}$. Alkohol akan menguap ketika proses pemanggangan sementara gas $\mathrm{CO}_{2}$ akan terperangkap di jaringan gluten. Semakin banyak ragi yang digunakan maka semakin banyak dan cepat perombakan gula menjadi alkohol dan $\mathrm{CO}_{2}$. Hal ini lah yang menyebabkan rasa manis pada roti (Sitepu, 2019)

\section{Tekstur}

Pengamatan terhadap tekstur dilihat dari nilai yang diperoleh, semakin tinggi nilai yang diperoleh maka semakin disukai oleh konsumen. Hasil pada Tabel 2 menunjukan nilai tekstur berkisar antara $5.81-6.38$. Semakin banyak menambahkan tepung pati temulawak, nilai tekstur semakin kecil. Berdasarkan hasil uji ANOVA yang menunjukan tidak ada perbedaan signifikan pada setiap perlakuan $(0.455>0.05)$, dimana menurut penilaian indra panelis, tekstur roti manis dengan penambahan MOTAF dan pati temulawak panelis mirip seperti roti manis $100 \%$ tepung terigu. Tekstur roti tawar dipengaruhi oleh beberapa faktor antara lain adanya kandungan protein, kadar air dan lemak dari bahan dasar pembuatan roti. Pori-pori roti yang terbentuk karena udara masuk kedalam adonan dan terdispersi dalam bentuk gelembung yang halus ketika tepung dan air dicampur dan diulen, karena dalam tepung terigu mengandung protein yang mampu membentuk gluten ketika 
ditambah air dan perlakuan mekanis (Nur'aini, 2011).

\section{Analisis Volume Spesifik}

Volume spesifik merupakan volume per satuan berat roti yang mencerminkan derajat pengembangannya. Nilai yang diharapkan adalah besar, semakin besar nilainya menggambarkan pengembangan rotinya semakin baik (Parwiyanti et al., 2019). Berdasarkan hasil yang didapat (Tabel 3) volume spesifik roti manis pada setiap perlakuan berbeda nyata $(\mathrm{p}<0.05)$.

Tabel 3. Volume Spesifik Roti Manis MOTAF Temulawak

\begin{tabular}{cc}
\hline Perlakuan & Volume Spesifik $\left(\mathbf{C m}^{3} / \mathbf{g}\right)$ \\
\hline A & $3,43 \pm 0,21^{\mathrm{b}}$ \\
B & $3,80 \pm 0,06^{\mathrm{c}}$ \\
C & $3,51 \pm 0,06^{\mathrm{bc}}$ \\
D & $3,21+0,26^{\mathrm{b}}$ \\
E & $2,82+0,19^{\mathrm{a}}$ \\
\hline
\end{tabular}

Ket: Rerata yang diikuti huruf yang berbeda dalam kolom yang sama menunjukan antar perlakukan berbeda nyata pada taraf signifikan $5 \%$

MOTAF dan pati temulawak tidak memiliki kandungan gluten. Menurut Yuwono dan Waziiroh (2019), gandum memiliki kandungan protein berkisar 9,5\% - 14,3\%, tergantung dari jenis gandumnya. Protein pada gandum terdapat kandungan gluten yang mencapai $80 \%$ dari total protein dalam tepung. Gluten ini berperan dalam pembentukan adonan yang kuat dan kohesif. Gluten mampu menahan gas pengembang $\mathrm{CO}_{2}$ yang terbentuk saat proses proofing oleh Saccaharomyces cerevisiae pada ragi sehingga membuat roti lebih baik. Menurut penelitian Mojiono et al (2012) gluten pada gandum akan mempengaruhi tekstur karena bersifat elastis sehingga kekerasan pada roti akan lebih rendah. Gluten mampu membentuk strutur adonan sehingga akan mengalami koagulasi saat adonan dipanggang. Hal tersebut berakibat pada tekstur yang lebih tegar dan akan mencegah roti mengempis (Damat et al., 2012), selain itu retrogradasi pati dapat mempengaruhi tekstur pada roti (Muflihati, et al., 2018). Oleh karena itu, semakin banyak penambahan pati temulawak membuat nilai volume spesifik lebih rendah.

\section{KESIMPULAN}

Berdasarkan hasil penelitian dapat disimpulkan bahwa roti manis dengan subtitusi MOTAF dan pati temulawak dapat diterima oleh konsumen baik dari segi rasa, aroma, tekstur. Semakin banyak penambahan pati temulawak akan membuat roti tidak mengembang baik, sehingga direkomendasikan penambahan pati temulawak pada pembuatan roti manis ini hanya sebesar 0,01 gram.

\section{UCAPAN TERIMAKASIH}

Penulis mengucapkan terima kasih kepada Politeknik Negeri Tanah Laut yang telah mendanai penelitian ini pada skema Penelitian Dosen Dana Dipa (PD3) tahun anggaran 2020.

\section{DAFTAR PUSTAKA}

AACC. Approved Methods of Analysis,. 2011. Methods: 74-09.01 (bread firmness), 10-05.01 (bread volume). 11th edition. Minnesota (US): American Association of Cereal Chemists.

BSN. 2006. SNI 01-2346 tentang Petunjuk Pengujian Organoleptik dan atau Sensori.

BPS. 2020. Statistical Yearbook of Indonesia, April. https://doi.org/10.3389/fpsyg.2015.0 0002

Damat, Ta'in, A., Handjani, H., Chasanah, U., Siskawardani D., 2017. Karakterisasi Roti Manis Dari Pati Garut Termodifikasi Dengan Penambahan Emulsifier Lesitin. 
Prosiding Seminar Nasional FKPTTPI, 20-21 September 2017. Kendari, Sulawesi Tenggara: 65-76.

Fatimah, E. Lestari, \& D. Sandri. 2017. Karakterisasi Tepung Biji Talipuk (Nymphaea pubescens Willd ) Termodifikasi Menggunakan Ragi Tape. Prosiding Seminar Nasional PATPI 2017, 10-12 November 2017, Bandar Lampung. 256-262.

Khamidah, A., Antarlina, S. S., \& Sudaryono, T. 2017. Ragam Produk Olahan Temulawak Untuk Mendukung Keanekaragaman Pangan. Jurnal Penelitian Dan Pengembangan Pertanian, 36(1): $1-12$.

https://doi.org/10.21082/jp3.v36n1. 2017.

Lestari, E., D. Sandri, Fatimah., 2019. Volume Kembang Adonan Dan Sensory Roti Manis Yang Dibuat Dari Modified Talipuk Flour (MOTAF). Jurnal Teknologi \& Industri Hasil Pertanian, 24(2): 113-120.

https://doi.org//10.23960/jtihp.v24i2

Lestari, E., Fatimah, D. Sandri, \& Yuniarti, R. 2019. Potensi Pati Temulawak Sebagai Bahan Pangan Pengganti Tepung Terigu Pada Kue Bolu. Jurnal Ilmu Pangan Dan Hasil Pertanian, 3(1): $60-67$. https://doi.org/10.26877/jiphp.v3i1. 3610

Mojiono, Jailani, F., Kusumawardani, S., Puspitasari, C., Maula, A., Purwandari, U., 2012. Modifikasi fisik (annealing) tepung uwi ungu untuk roti tawar tersubstitusi dan indeks glikemiknya. Prosiding Seminar Nasional : Kedaulatan Pangan dan Energi, 12 Juni 2012. Fakultas Pertanian Universitas Trunojoyo Madura. 313-320.
Muflihati, I., et al., 2018. Sifat Fisikokimia dan Sensoris Roti Hasil Substitusi Pati Ganyong yang Dimodifikasi Melalui Irradiasi Sinar UV-C. Jurnal Ilmiah Teknosains. 4(1): 1115.

Nur'aini, A. 2011. “Aplikasi Millet (Pennisetum Spp) Merah dan MilletKuning sebagai Substitusi Terigu dalam Pembuatan Roti Tawar :Evaluasi Sifat Sensoris dan Fisikokimia". Skripsi. Universitas Sebelas Maret, Surakarta.

Parwiyanti, P., Pratama, F., Wijaya, A., \& Malahayati, N. 2019. Karakteristik Roti Bebas Gluten Berbahan Dasar Pati Ganyong Termodifikasi. AgriTECH, 38(3): 337-334. https://doi.org/10.22146/agritech.16 946

Richana, Nur. 2010. Tepung jagung termodifikasi sebagai pengganti Terigu. Warta Penelitian dan Pengembangan Pertanian 32(6): 57

Rosidi, A., Khomsan, A., Setiawan, B., Riyadi, H., \& Briawan, D. 2014. Potensi Temulawak (Curcuma xanthorrhiza Roxb) Sebagai Antioksidan. Prosiding Seminar Nasional Hasil-Hasil Penelitian \& Pengabdian. 9 Agustus 2014, Universitas Muhammadiyah Semarang, Semarang.

Sitepu, K. M. 2019. Penentuan Konsentrasi Ragi Pada Pembuatan Roti. Jurnal Penelitian Dan Pengembangan Agrokompleks, 2(1), 71-77

Subagja, H.P. 2014. Temulawak Itu Ajaib! Rimpang Ajaib PembasmiBeragam Penyakit. Cetakan Pertama. Penerbit FlashBooks, Yogyakarta. 148 hlm.

Sutriono, Y. dan U. Pato. 2016. Pemanfaatan buah terung belanda 
dan kulit pisang kepok dalam pembuatan selai. Jom Faperta. 3(2):1 -13.
Teknologi Pengolahan Tepung Terigu dan Olahannya di Industri. UB Press. Malang.

Yuwono, S.S., dan E. Waziiroh. 2019. 